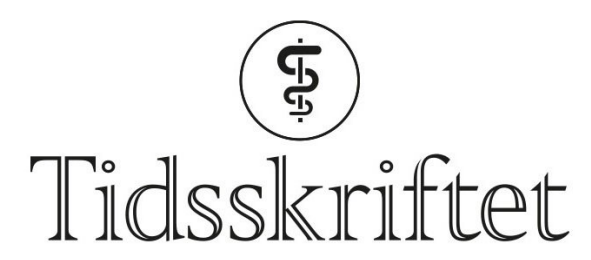

DEN NORSKE LEGEFORENING

\title{
Hippokratisk revisjon
}

MINILEDER

ARE BREAN

Sjefredaktør

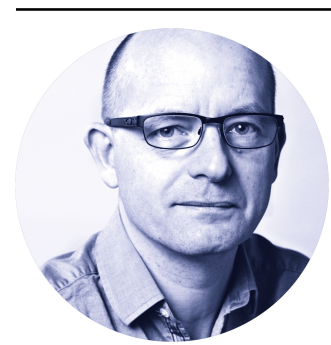

17. oktober 2017 vedtok Verdens legeforening (World Medical Association) en revidert versjon av den universelle legeeden. Legeeden, kjent som Genève-deklarasjonen, ble opprinnelig vedtatt i 1948, som en videreutvikling og modernisering av den hippokratiske ed. Bakgrunnen var ikke minst uhyrlighetene som ble begått under den annen verdenskrig. Legene var tidlig ute - først tre måneder senere ble den universelle Menneskerettighetserklæringen vedtatt av FN.

Den revisjonen som nå er gjort, har medført flere viktige endringer. Prinsippet om pasientautonomi er tydeliggjort, og pasientens rettigheter er fremhevet enda mer enn før. Det samme er legens plikt til å utføre sin gjerning i tråd med "god medisinsk praksis». Og for første gang er legens plikt til å ta vare på seg selv tatt med i eden: "Jeg vil ivareta min egen helse, mitt velvære og mine evner, for å kunne gi omsorg av den høyeste standard.» Det siste er en nyttig påminnelse for oss alle i en tid med stadig økende produktivitetskrav. Som leger har vi en selvstendig plikt til å ta vare på oss selv, også av hensyn til våre pasienter.

Publisert:30. oktober 2017. Tidsskr Nor Legeforen. DOI:10.4045/tidsskr.17.20.01

(C) Tidsskrift for Den norske legeforening 2020. Lastet ned fra tidsskriftet.no 